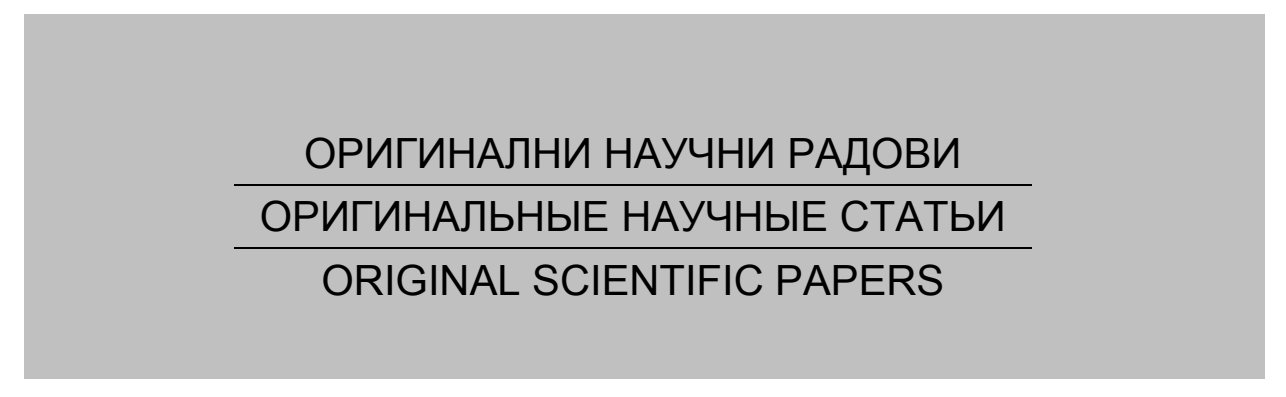

\title{
NEW BOUNDS FOR LAPLACIAN ENERGY
}

\section{Ivan Gutman}

University of Kragujevac, Faculty of Science, Kragujevac, Republic of Serbia, e-mail: gutman@kg.ac.rs, ORCID iD: (1)http://orcid.org/0000-0001-9681-1550

DOI: 10.5937/vojtehg68-24257; https://doi.org/10.5937/vojtehg68-24257

FIELD: Mathematics (Mathematics Subject Classification: primary 05C50, secondary 05C90)

ARTICLE TYPE: Original Scientific Paper ARTICLE LANGUAGE: English

\begin{abstract}
:
Introduction/purpose: The Laplacian energy (LE) is the sum of absolute values of the terms $\mu_{i}-2 m / n$, where $\mu_{i}, i=1,2, \ldots, n$, are the eigenvalues of the Laplacian matrix of the graph $G$ with $n$ vertices and $m$ edges. The basic results of the theory of $L E$ are outlined, and some new obtained. Methods: Spectral theory of Laplacian matrices is applied. Results: A new class of lower bounds for $L E$ is derived. Conclusion: The paper contributes to the Laplacian spectral theory and tp the theory of graph energies.
\end{abstract}

Keywords: spectral graph theory, Laplacian spectrum (of graph), Laplacian energy.

\section{Introduction}

Throughout this paper, we are concerned with simple graphs, i.e. graphs without directed, multiple, or weighted edges, and without loops. Let $G$ be such a graph, possessing $n$ vertices and $m$ edges. For details of the graph theory see (Harary, 1969), (Cvetković, 1981).

Let the vertices of the graph $G$ be labeled by $v_{1}, v_{2}, \ldots, v_{n}$. Let $\operatorname{deg}\left(v_{\mathrm{i}}\right)$ be the degree (= number of first neighbors) of the vertex $v_{\mathrm{i}}$. Then the Laplacian matrix of $G$, denoted by $L(G)$, is the square matrix of the order $n$, whose $(i, j)$-element is equal to -1 if the vertices $v_{i}$ and $v_{j}$ are adjacent, it is 0 when the vertices $v_{\mathrm{i}}$ and $v_{\mathrm{j}}$ are not adjacent, and $\operatorname{deg}\left(v_{\mathrm{i}}\right)$ if $i=j$. The eigenvalues of $L(G)$, denoted bu $\mu_{i}, i=1,2, \ldots, n$, form the Laplacian spectrum of the graph $G$. For details of the theory of Laplacian matrices and their spectra see (Grone et al, 1990), (Merris, 1994). 
The (ordinary) energy of a graph is defined as the sum of absolute values of the eigenvalues of the adjacency matrix ( $\mathrm{Li}$ et al, 2012), (Gutman \& Furtula, 2019). Extending this concept to Laplacian eigenvalues, the Laplacian energy was defined as (Gutman \& Zhou, 2006):

$$
L E=\sum_{i=1}^{n}\left|\mu_{i}-\frac{2 m}{n}\right| .
$$

For details on the mathematical properties of the Laplacian energy see (Andriantiana, 2016), (Gutman \& Furtula, 2019).

\section{Preparations and the main results}

The Laplacian eigenvalues $\mu_{i}, i=1,2, \ldots, n$, are non-negative real numbers. If the underlying graph $G$ is connected, then exactly one of these eigenvalues is equal to zero (and the other $n-1$ eigenvalues are positive-valued). The following relations

$$
\sum_{i=1}^{n} \mu_{i}=2 m
$$

and

$$
\sum_{i=1}^{n} \mu_{i}^{2}=2 m+\sum_{i=1}^{n} \operatorname{deg}\left(v_{i}\right)^{2}
$$

are well known (Grone et al, 1990). At this point, we note that the sum of squares of vertex degrees is the much studied first Zagreb index; for details see (Borovićanin et al, 2017) and the references cited therein.

Combining Eqs. (2) and (3), we directly obtain

$$
\sum_{i=1}^{n}\left|\mu_{i}-\frac{2 m}{n}\right|^{2}=2 M
$$

where

$$
M=m-\frac{2 m^{2}}{n}+\frac{1}{2} \sum_{i=1}^{n} \operatorname{deg}\left(v_{i}\right)^{2}
$$

Numerous upper and lower bounds for the Laplacian energy are known (Gutman \& Zhou, 2006), (Andriantiana, 2016), of which we mention here 


$$
2 \sqrt{M} \leq L E \leq 2 M
$$

and the McClelland-type upper bound

$$
L E \leq \sqrt{2 M n} .
$$

In this paper, we offer four new lower bounds for $L E$, namely

$$
\begin{aligned}
& L E>\frac{a b n+2 M}{a+b} \\
& L E>\frac{2 m}{n}+\frac{a b(n-1)+2 M-\left(\frac{2 m}{n}\right)^{2}}{a+b} \\
& L E>\frac{2 \sqrt{a b}}{a+b} \sqrt{2 M n} \quad \frac{2 m}{n}+\frac{2 \sqrt{a b}}{a+b} \sqrt{\left[2 M-\left(\frac{2 m}{n}\right)^{2}\right](n-1)} \\
& L E>\frac{2 M}{[2}
\end{aligned}
$$

For connected graphs with at least four vertices, all bounds (6)-(9) are strict.

The meaning of the parameters $a$ and $b$ is explained in the subsequent section. Observe that the multiplier in (8) and (9) is the ratio between the geometric and arithmetic means of $a$ and $b$.

\section{Proofs of bounds (6)-(9)}

In order to avoid trivialities, we assume that the graphs considered are connected and have more than three vertices. Let

$$
\left|\mu_{i}-\frac{2 m}{n}\right|=X_{i}
$$

and label the Laplacian eigenvalues of the considered graph so that $X_{1} \geq X_{2} \geq \cdots \geq X_{n}$.

In addition, let $X_{1}=a$ and $X_{n}=b$. Then 


$$
\left(a-X_{i}\right)\left(b-X_{i}\right)=\mathrm{ab}-(\mathrm{a}+\mathrm{b}) \mathrm{X}_{i}+X_{i}^{2} \leq 0
$$

holds for all $i=1,2, \ldots, n$, and is strictly negative for at least one value of $i$. Summing (10) over all $i$, and bearing in mind Eqs. (1) and (4), we get

$$
a b n-(a+b) L E+2 M<0
$$

from which inequality (6) directly follows.

For connected graphs, exactly one Laplacian eigenvalue is equal to zero. Therefore, one $X$-value is equal to $2 \mathrm{~m} / \mathrm{n}$. Let this be $X_{\# \text {. }}$

If we sum (10) over all $i$, except $i=\#$, then we arrive at

$$
a b(n-1)-(a+b)\left(L E-\frac{2 m}{n}\right)+\left[2 M-\left(\frac{2 m}{n}\right)^{2}\right]<0
$$

which implies inequality (7).

Applying the relation $P+Q \geq 2 \sqrt{P Q}$, which holds for any positive real numbers $P, Q$, with equality if and only if $P=Q$, we can transfer inequality (6) into inequality (8). In the very same manner, bound (9) is obtained from (7).

It is worth noting that the lower bound (8) has a similar algebraic form as the upper bound (5). Thus (5) and (8) estimate the Laplacian energy from both sides in an analogous, McClelland-type manner.

It can be shown that among the lower bounds (6)-(9), bound (7) is the best. In addition, (6) is better than (8), whereas (7) is better than (9). Numerical testing shows that bound (6) is sharper than $\{9$ ), However, to verify this by exact mathematical methods seems to be a tough task and remains an open problem.

\section{A special case: regular graphs}

A graph is said to be regular if all its vertices have equal degrees. Let, thus, the considered graph $G$ be regular, and let $\operatorname{deg}\left(v_{i}\right)=r$ for all $i=1,2, \ldots, n$. Then

$$
\sum_{i=1}^{n} \operatorname{deg}\left(v_{i}\right)=n r, \sum_{i=1}^{n} \operatorname{deg}\left(v_{i}\right)^{2}=n r^{2}, \frac{2 m}{n}=r, M=m .
$$
to:

Bearing this in mind, for regular graphs, inequalities (6)-(9) reduce 


$$
\begin{aligned}
& L E>\frac{(a b+r) n}{a+b} \\
& L E>r+\frac{a b(n-1)+r(n-r)}{a+b} \\
& L E>\frac{2 \sqrt{a b}}{a+b} n \sqrt{r} \\
& L E>r+\frac{2 \sqrt{a b}}{a+b} \sqrt{r(n-r)(n-1)}
\end{aligned}
$$

For regular graphs, the Laplacian and ordinary energies coincide. Therefore, bounds (6a)-(9a) hold also for the ordinary energy of regular graphs. Bounds of this kind (for ordinary graph energy) were recently communicated (Oboudi, 2019), (Gutman, 2019).

\section{References}

Andriantiana, E.O.D. 2016. Laplacian energy. In: Gutman, I. \& Li, X. (Eds.), Graph Energies - Theory and Applications.Kragujevac: University of Kragujevac, pp.49-80.

Borovićanin, B., Das, K.C., Furtula, B., \& Gutman, I. 2017. Bounds for Zagreb indices. MATCH Communications in Mathematical and in Computer Chemistry, 78(1), pp.17-100 [online]. Available at: http://match.pmf.kg.ac.rs/electronic_versions/Match78/n1/match78n1_17100.pdf. [Accessed: 30 November 2019]

Cvetković, D. 1981. Teorija grafova i njene primene.Belgrade: Naučna knjiga (in Serbian).

Grone, R., Merris, R., \& Sunder, V.S. 1990. The Laplacian Spectrum of a Graph. SIAM Journal on Matrix Analysis and Applications, 11(2), pp.218-238. Available at: https://doi.org/10.1137/0611016.

Gutman, I. 2019. Oboudi-type bounds for graph energy. Mathematics Interdisciplinary Research, 4(2), pp.151-155 [online]. Available at: http://mir.kashanu.ac.ir/article_96938_35e2a0e7a15dcdd1e796325b33542469.p df. [Accessed: 30 November 2019]

Gutman, I., \& Furtula, B. 2019. Graph Energies: Survey, Census, Bibliography.Kragujevac: Centar SANU. Bibliography.

Gutman, I., \& Zhou, B. 2006. Laplacian energy of a graph. Linear Algebra and its Applications, 414(1), pp.29-37. Available at: https://doi.org/10.1016/j.laa.2005.09.008.

Harary, F. 1969. Graph Theory.Addison-Wesley. Reading. 


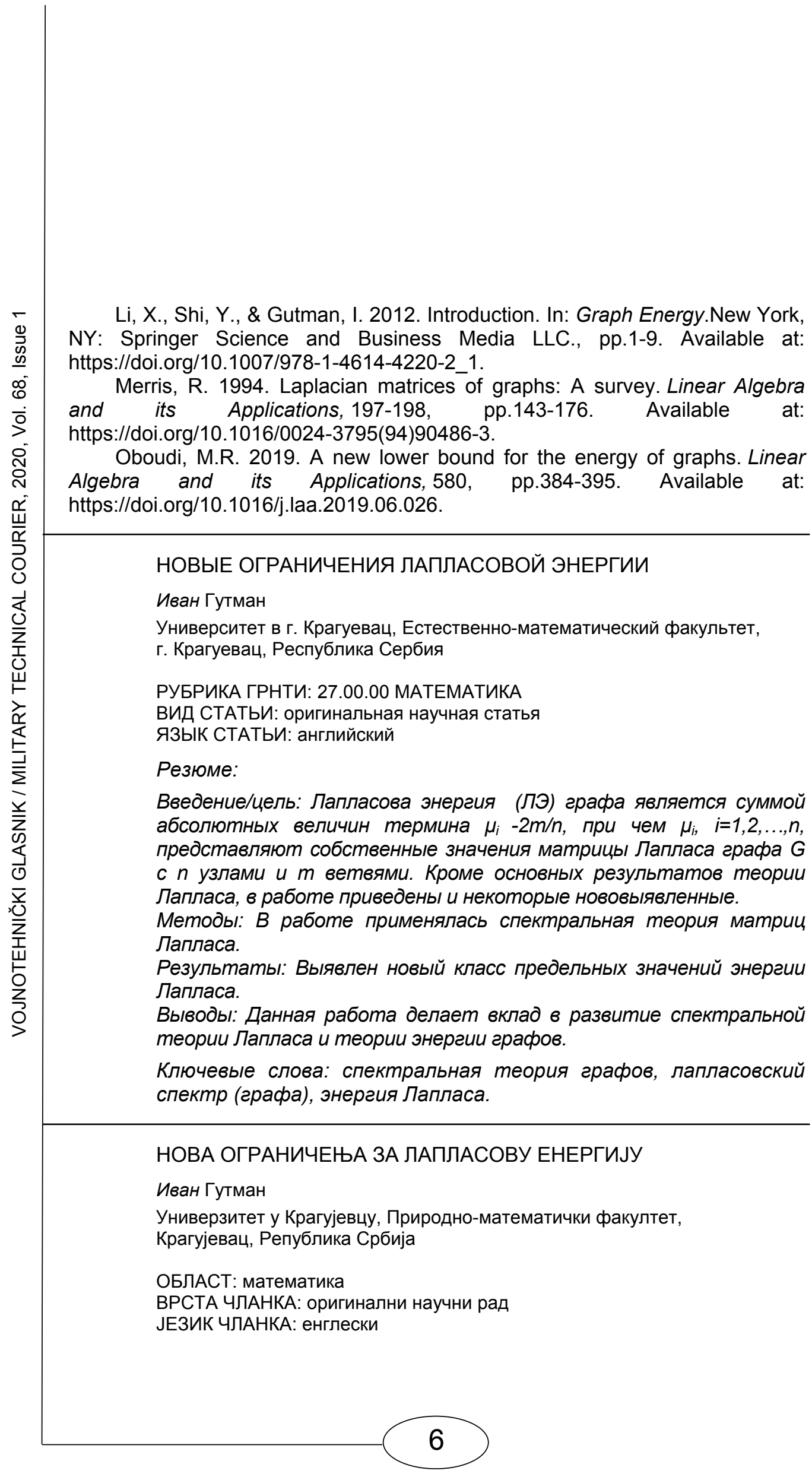




\section{Сажетак:}

Увод/сврха: Лапласова енергија (LE) графра је сума апсолутних вредности израза $\mu_{i}-2 m / n$, где $\mu_{i}, \quad i=1,2, \ldots, n, \quad$ представљају сопствене вредности Лапласове матрице графра $G$ са $n$ чворова $u$ $m$ грана. Поред основних резултата теорије Лапласове енергије дати су и неки новодобијени.

Методе: Коришћена је спектрална теорија Лапласових матрица. Резултати: Изводи се нова класа доњих ограничења за Лапласову енергију.

Закључак: Рад даје допринос Лапласовој спектралној теорији као и теорији енергија графра.

Кључне речи: спектрална теорија графрова, Лапласов спектар (графра), Лапласова енергија.

Paper received on / Дата получения работы / Датум пријема чланка: 01.12.2019. Manuscript corrections submitted on / Дата получения исправленной версии работы / Датум достављања исправки рукописа: 20.12.2019.

Paper accepted for publishing on / Дата окончательного согласования работы / Датум коначног прихватања чланка за објављивање: 22.12.2019.

(C) 2020 The Author. Published by Vojnotehnički glasnik / Military Technical Courier (www.vtg.mod.gov.rs, втг.мо.упр.срб). This article is an open access article distributed under the terms and conditions of the Creative Commons Attribution license (http://creativecommons.org/licenses/by/3.0/rs/).

(c) 2020 Автор. Опубликовано в «Военно-технический вестник / Vojnotehnički glasnik / Military Technical Courier» (www.vtg.mod.gov.rs, втг.мо.упр.срб). Данная статья в открытом доступе и распространяется в соответствии с лицензией «Creative Commons» (http://creativecommons.org/licenses/by/3.0/rs/).

(c) 2020 Аутор. Објавио Војнотехнички гласник / Vojnotehnički glasnik / Military Technical Courier (www.vtg.mod.gov.rs, втг.мо.упр.срб). Ово је чланак отвореног приступа и дистрибуира се у складу са Creative Commons licencom (http://creativecommons.org/licenses/by/3.0/rs/). 